\title{
Impact of mirror movements on the bimanual hand function and functional independence with comparison of the bimanual hand function in children suffering from spastic cerebral palsy, with and without mirror movements
}

\author{
Javeria SHAHID', Misbah MARRYAM², Sheema KHAN,,3Muhammad UMAR ${ }^{4}$
}

\begin{abstract}
Objective: To compare the bimanual hand function in children with and without mirror movements and to find the correlation between the bimanual hand function, functional independence and severity of mirror movements.

Design: Comparative cross sectional study.

Place and duration of the study: The study was conducted in special education schools of Lahore and Islamabad, Pakistan, from August 2017 to January 2018.

Patients and Methods: Children suffering from spastic cerebral palsy including both males and females in age groups ranging from 5 to 18 years who were able to make a gross grip were included in the study. Children having low tone, not able to make a gross grip and with any deformity that makes the assessment difficult were excluded. The non probability sampling technique was used. The Woods and Teuber criteria were used to check the severity of the mirror movements and bimanual activities to compare the hand functions. Data was analyzed using SPSS 21.

Results: The mean age of the participants was $11.17 \pm 3.69$ years. Children who presented with mirror movements had a mean age of $12 \pm 3.70$ years and those without mirror movements had mean age of $10.72 \pm 3.63$ years. According to the results of the bimanual task scale, there was no difference in the bimanual hand function of children with mirror movements and without mirror movements ( $\mathrm{P}$ value $>0.05$ )

Conclusion: According to the results of the bimanual task scale there is no significant difference in the bimanual hand function of children suffering from spastic cerebral palsy, either with with or without mirror movements. However, functional independence was found more in the children suffering from cerebral palsy who presented without mirror movements.
\end{abstract}

Key words: spastic cerebral palsy, mirror movements

\section{Rezumat}

Obiectiv: Compararea bimanualității la copiii cu sau fără mișcări în oglindă și găsirea de corelații între bimanualitate, independența funcțională și gravitatea mișcărilor în oglindă.

Design: Studiu transversal comparativ.

Locul și durata desfăşurării studiului: Studiul s-a realizat în școli speciale din Lahore și Islamabad, Pakistan, în perioada august 2017 - ianuarie 2018.

Pacienți și metode: În studiu au fost inluși copii cu paralizie cerebrală spastică, fete și băieți, din grupe de vârstă cuprinse între 5 și 18 ani, care puteau efectua prinderi brute. Copiii cu hipotonie, care nu puteau realiza prinderi brute și cu diformități care îngreunau evaluarea au fost excluși. S-a folosit tehnica eșantionării aleatorie. S-au folosit criteriile Woods și Teuber pentru verificarea gravității mișcărilor în oglindă și a activităților bimanuale pentru a se compara funcțiile mâinii. Datele au fost analizate cu ajutorul SPSS 21.

\footnotetext{
${ }^{1}$ Doctor of Physical therapy, Masters in Neuromuscular physical therapy, House officer, Railway general hospital, Rawalpindi, Pakistan, $e$ mail: jiahaq12@gmail.com

2 Physiotherapist, Benazir Bhutto hospital, Rawalpindi, Pakistan

${ }^{3}$ House officer, Railway general hospital, Rawalpindi, Pakistan

${ }^{4}$ Head of Physiotherapy department, Holy family hospital, Rawalpindi, Pakistan
} 


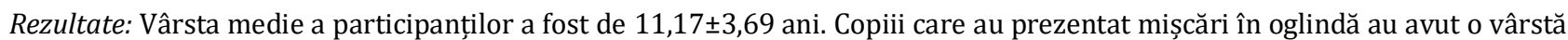
medie de $12 \pm 3,70$ ani, iar cei fără mișcări în oglindă au avut o vârstă medie de 10,72 $\pm 3,63$ ani. Conform rezultatelor obținute cu ajutorul scalei sarcinii bimanuale nu a existat nicio diferență între funcția bimanualității la copiii cu mișcări în oglindă și la cei mișcări în oglindă (valoarea $\mathrm{P}>0,05$ )

Concluzie: Conform rezultatelor obținute cu ajutorul scalei sarcinii bimanuale nu există niciun fel de diferență semnificativă referitoare la bimanualitatea copiilor care suferă de paralizie cerebrală spastică, cu sau fără mișcări în oglindă. Cu toate acestea, independența funcțională este mai prezentă la copiii cu paralizie cerebrală spastică care nu au prezentat mișcări în oglindă.

Cuvinte cheie: paralizie cerebrală spastică, mișcări în oglindă 


\section{Introduction}

Cerebral palsy is a group of permanent disorders of movement and/or posture and of motor function, which are due to a non-progressive interference, lesion, or abnormality of the developing/immature brain [1]. The etiology of Cerebral Palsy is very diverse and multifactorial. Major causes are congenital, genetic, inflammatory, infectious, anoxic, traumatic and metabolic. The injury to the developing brain may be prenatal, natal or postnatal [2]. As much as $75 \%-80 \%$ of the cases are due to prenatal injury with less than $10 \%$ being due to significant birth trauma or asphyxia [3]. Literature suggests prematurity and low birth weight to be an important risk factor for the disorder. The chances of cerebral palsy increase with decreased gestational age and birth weight [4].

Cerebral palsy presents itself in different forms which may include: spastic, flaccid, dyskinetic and ataxic forms. In the spastic and flaccid type, the classic presentation is as hypertonia and hypotonia, respectively. In other forms such as ataxic cerebral palsy, the patient presents as having problems with balance and depth perception and the dyskinetic type leads to involuntary and uncontrolled movements. [5]. Cerebral palsy includes some movement disorders like tremors, ballism, myoclonus, tics, dystonia, chorea athetoid and mirror movements. Cerebral palsy causes delayed development with exaggerated reflexes, floppiness or unbending nature of the appendages and trunk, anomalous stance; automatic developments, temperamental strolling, or sometimes mixture of these [6].

Mirror movements are simultaneous, involuntary, contralateral identical movements that occur with voluntary movements. Mirror movements primarily involve upper limbs, especially hands and fingers. Classical examples include making a fist with the right hand followed by the left hand and vice versa [7]. The congenital mirror movement disorder can occur due to mutations in the DCC or RAD51 gene; mutations in these genes account for $35 \%$ of the cases. Mutations in the DCC gene result in an impaired or missing netrin-1 receptor protein which is involved in the development of the nervous system [8]. A shortage of the functional netrin-1 receptor protein impairs the control of axon growth during the development of the nervous system.

Mild mirror movements are common during the normal development of young children, they can also develop later in life, in people with neurodegenerative disorders such as Parkinson disease [9].

As far as we know, there is no study conducted in Pakistan with focus on mirror movements and their influence on the bimanual hand function in children suffering from spastic cerebral palsy.

This movement disorder is often mixed or confused with associated movements. The purpose of the study was to determine the difference in the bimanual hand function in children suffering from spastic cerebral palsy, with and without mirror movements. It was also designed to find the impact of mirror movements on bimanual tasking and functional independence in children affected by spastic cerebral palsy with mirror movements, so that a quality treatment may be provided to the children having mirror movements that will impact hand function.

\section{Methods}

A comparative cross sectional study was conducted in special education schools of Lahore and Islamabad, Pakistan from August 2017 to January 2018. The data was collected using the Non probability purposive sampling technique.

One hundred forty children with spastic cerebral palsy (hemiplegic, diplegic and quadriplegic), both male and female, between 5 and 18 years of age, who were able to make a gross grip were included in the study. All the cerebral palsy children presenting with low tone having fixed deformities or who were not able to follow the command were excluded from the study.

To measure the severity of mirror movements, the Wood and teuber criteria were used. It consists of five grades, in which grade 0 shows no clear mirror movement and grade 4 shows a mirror movement equal to that of the opposite hand. Movements were graded while performing three tasks i.e. opening and clenching of fist, finger opposition and tapping; all the tasks were videotaped [10]. To check the functional independence of cerebral palsy children, the manual ability classification system was used consisting of five levels in which, level I denotes that the patient handles objects easily and successfully and level $\mathrm{V}$ shows that the child does not hold any object [11]. To compare the bimanual hand function, bimanual activities were performed which consisted of different tasks such as carrying a tray, opening a bottle, cutting a fruit, holding and cutting paper with scissors, buttoning and tying a knot. For each task, the degree of assistance was graded from grade 0 (non existent) to grade 3 (normal) [10,12].

All these tasks were performed under the supervision of a trained therapist while during the performance of tasks, a class teacher was present to make the environment more comfortable for the child. Between fifteen to twenty minutes were spent on every individual for data collection. Data was analyzed by using SPSS 21. The Mann-Whitney $U$ test was applied after checking the normality of the data using the Kolomogorov - Smirnov test for comparison between the groups (children with \& without mirror movements).

Also, the Spearman rank correlation was used for finding the correlation of mirror movements with bimanual tasking and functional independence. 


\section{Results}

The mean age of the participants with mirror movements was $12.0 \pm 3.70$ years and $10.72 \pm 3.63$ years in children without mirror movements. In the current study, out of a total of 140 participants, $113(80.7 \%)$ were male and 27 $(19.3 \%)$ were female. The majority of patients in the study had diplegic cerebral palsy with a frequency of 51 (36.4\%), followed by hemiplegic cerebral palsy 50 (35.7\%) and then the quadriplegic 39 (27.9\%). While the most commonly affected side was the bilateral upper limb $89(63.6 \%)$.

It was found that $50(35.7 \%)$ of the participants were affected by mirror movements, while 90 (64.3\%) were found to be non-affected. Mirror movements were observed at the highest level in grade 1 , followed by grade 2 , while no mirror movements were observed in grades 3 and 4 . Most mirror movements were observed while performing the opening and clenching of fist (26.4\%) followed by finger opposition (8.6\%) and the least in tapping $(2.1 \%)$. Regarding hand function, most of the children presenting with mirror movements fall in level II (44\%) and level III $(30 \%)$, and children presenting without mirror movements were more frequently included in levels I (41.1\%) and II (36.7\%) showing improved hand function compared to the children with mirror movements.

The results showed no significant difference in the bimanual hand function of children suffering from spastic cerebral palsy with mirror movements and without mirror movements, as the $\mathrm{P}$ value is greater than 0.05 . But the children without mirror movements have better hand function as compared to the children with mirror movements, as shown in table I.

Table I. The Mann - Whitney U test on bimanual tasks

\begin{tabular}{|c|c|c|c|c|c|}
\hline \multirow[t]{2}{*}{$\begin{array}{l}\text { Components of } \\
\text { bimanual activities }\end{array}$} & \multicolumn{2}{|c|}{ Mirror movements } & \multicolumn{2}{|c|}{$\begin{array}{lll}\text { Without mirror movement } \\
\text { median IQ }\end{array}$} & \multirow[t]{2}{*}{ p value } \\
\hline & Median (IQR) & Mean Ranks & Median (IQR) & Mean Ranks & \\
\hline Carrying a tray & $3(3-2)$ & 69.44 & $3(3-2)$ & 71.09 & .791 \\
\hline Opening a bottle & $2(3-2)$ & 58.29 & $2(3-2)$ & 77.28 & .004 \\
\hline Cutting a fruit & $2(3-2)$ & 67.24 & $2(3-2)$ & 72.31 & .444 \\
\hline $\begin{array}{l}\text { Holding and cutting } \\
\text { paper }\end{array}$ & $2(3-0)$ & 62.60 & $2(3-0)$ & 74.89 & .072 \\
\hline Buttoning & $2(3-0)$ & 66.22 & $2(3-0)$ & 72.88 & .333 \\
\hline Tying a knot & $0(2-0)$ & 73.80 & $0(2-0)$ & 68.67 & .424 \\
\hline
\end{tabular}


According to the results, the severity of the mirror movements did not affect the bimanual hand function of the children as the $P$ value $>0.05$. But a positive correlation was found between the manual ability classification system and the mirror movements showing a lower functional independence with the increase in mirror movements. As the severity of mirror movements increases, the score on the manual ability classification system also increases showing less independence with the increased mirror movements, as the $\mathrm{P}$ value is less than 0.05 (table II).

Table II. Spearman's rank correlation between the bimanual task, MACS and the severity of mirror movements

\begin{tabular}{|c|c|c|}
\hline Variable & Correlation coefficient & P value \\
\hline $\begin{array}{l}\text { Bimanual tasking and severity of } \\
\text { mirror movements }\end{array}$ & -0.01 & 0.23 \\
\hline $\begin{array}{l}\text { MACS and severity of mirror } \\
\text { movements }\end{array}$ & 0.27 & $0.001^{* *}$ \\
\hline
\end{tabular}




\section{Discussion}

In the current study, the bimanual hand function was compared in children suffering from spastic cerebral palsy who presented with and without mirror movements, and it was found that mirror movements do not disturb the bimanual hand functions. Johann et al. carried out a study on the assessment of mirror movements in children and adolescents with hemiplegic cerebral palsy. Twenty two participants were included (aged 6 to 18 years), 19 participants were having mirror movements. Mirroring was more prominent in the unaffected hand. Mirror movements disturbed the functional bimanual skills [10]. However in the current study, no significant difference was found in children presenting with and without mirror movements. The major reason could be that most children in the current study were found in grade 1 of mirror movements and were able to make the gross grip which may have shown no difference in the hand function of children with and without mirror movements. In addition, in the current study, the functional independence of the children was also evaluated by using MACS. Cerebral palsy children with mirror movements fall highest in levels II and III of the MACS scale showing a difference in the two groups, i.e. with and without mirror movements. Rice et al. carried out a study on the spectrum of movement disorders in the cerebral palsy population with the gross motor functional classification system and manual ability classification system scale; their results revealed that mirror movements were present in $10 \%$ of the children and mostly occurred in children with mild to moderate motor impairment (GMFCS I-III, MACS 1 to 3 [11]. The results are inconsistent with the results of the current study.

Adler et al. carried out a study on Mirror movements in unilateral spastic cerebral palsy to check the specific negative impact on bimanual activities of daily living and concluded that mirror movements indeed have a specific negative impact on bimanual performance. This study assessed both the unimanual and bimanual tasks of daily living [12]. However, in the current study only the bimanual hand function was assessed when performing bimanual activites of daily living and it was found that mirror movements do not affect the bimanual hand function in children with spastic cerebral palsy. This contradiction in results might have occurred as most mirror movements were observed in grade 1 and children were able to make the gross grip and also the sample size was small. Ruth Nass et al. carried out a study on mirror movement asymmetries in congenital hemiparesis and concluded that mirror movements are seen in normal children in the first decade. The movements persist after age 10 in patients with congenital hemiparesis. At first, mirror movements are more prominent in the good hand, but after age 10, mirroring diminishes in the good hand thus making the hand free for all dissociated functional activities but the affected hand still has these movements affecting the quality of life [13]. In the current study children with cerebral palsy (aged 5 to 18) were included and it was observed that the mean age of mirror movements was 11 and mirror movements were more common in the unaffected side, as most of the patients have ages near age 10 , but also movements were present in the affected hand.

Kartrijn et al. carried out a study to find the association of mirror movements with hand function in children with unilateral cerebral palsy and concluded that mirror movements in the non-paretic hand seems related to hand function while mirror movements in the paretic hand seems related to the lesion timing while children with earlier lesion present with more mirror movements. The Jebsen Taylor hand function test was used to perform unimanual tasks while the assisting hand assessment AHA was used to evaluate the bimanual task [14]. In the current study, the bimanual hand function was assessed but due to permission issues the AHA was not used; however the correlation between the severity of mirror movements, bimanual task and MACS were found and it was found that bimanual functioning is not affected by mirror movements. However, functional independence was affected by the severity of mirror movements. Ermellina et al. carried out a study on hand function in children with hemiplegic cerebral palsy. They carried out a prospective follow-up consisting of video-recorded procedures: one to assess grip and the other to assess the extent of the spontaneous use of the affected hand and concluded that to evaluate the real disability of the affected hand in children with hemiplegia, grip assessment is insufficient and that an instrument assessing spontaneous hand use in bilateral manipulation is required [15]. While in the current study unimanual hand function was not checked and to check mirror movements video recording was done while doing opening and closing the fist, finger opposition and tapping. Although no grip testing using a specific instrument was performed, bimanual activities of daily living were performed with some items that require grip formation and no significant difference was found in the bimanual hand function of children with and without mirror movements.

Charles et al. assessed the unimanual and bimanual fingertip force control during grasping in children with hemiplegic cerebral palsy (CP). Participants lifted, transported and released an object with one hand or both hands together in order to examine the effect on fingertip force control for each hand separately and to determine whether any benefit exists for the affected hand when it performed the task concurrently with the less-affected hand. The results showed slowing down of the less- 
affected hand when it moved together with the affected hand and that bimanual tasks may have the potential to facilitate force control of the affected hand [16]. While in the current study fingertip force or dexterity was not assessed, griping was assessed while performing bimanual ADLs.

The unequal gender distribution, small sample size, small study duration, assessment of the bilateral hand function without a standardized tool and no comparison of paretic and non paretic hand function were the few limitations of the study. Future studies should be conducted with different study designs as these mirror movements require some form of treatment to improve the function of the individual in performing activities of daily living. The unilateral hand function should be compared between the groups with and without mirror movements. Mirror movements should be evaluated more specifically for different types of spastic cerebral palsy, as well as with other types.

\section{Conclusion}

Mirror movements do not affect the bimanual activities of children suffering from spastic cerebral palsy, neither their severity has any effect on bimanual activities. Functional independence was found more in children who presented without mirror movements compared to children with mirror movements. The severity of mirror movements decreases the functional independence of the upper limb of the child presenting with mirror movements.

Disclaimer: None to declare.

Conflict of interest: None to show.

Source of funding: There was no source of funding.

Acknowledgment: The authors would like to acknowledge Dr. Tasnim Waheed and Dr. Fazal Cheema for their support regarding the permission issuance from different special education schools in Lahore and Islamabad.

\section{References}

1. Rosenbaum P., Paneth N., Leviton A., Goldstein M., Bax M., Damiano D., Dan B., Jacobsson B. (2007). A report: the definition and classification of cerebral palsy April 2006, Developmental Medicine and Child Neurology. Supplement, 109, 8-14.

2. Bax M., Goldstein M., Rosenbaum P., Leviton A., Paneth N., Dan B., Jacobsson B., Damiano D. (2005). Proposed definition and classification of cerebral palsy, Developmental Medicine and Child Neurology, 47(8), 571-6.

3. Nelson K.B., Grether JK. (1996). Causes of cerebral palsy, Current Opinion in Pediatrics,11(6), 487-91.
4. Krigger K.W. (2006). Cerebral palsy: an overview, American Family Physician, 73(1).

5. Morris C. (2007). Definition and classification of cerebral palsy: a historical perspective, Developmental Medicine \& Child Neurology, 49(s109), 3-7.

6. Srour M., Rivière J.B., Pham J.M., Dubé M.P., Girard S., Morin S., Dion P.A, Asselin G., Rochefort D., Hince P., Diab S. (2010). Mutations in DCC cause congenital mirror movements, Science, 328(5978), 592.

7. Woods B.T., Teuber H.L. (1978). Mirror movements after childhood hemiparesis, Neurology, 28, 1152-1158.

8. Armatas C.A., Summers J.J., Bradshaw J.L. (1994). Mirror movements in normal adult subjects, Journal of Clinical and Experimental Neuropsychology, 16(3), 405-13.

9. Steenbergen B., Gordon A.M. (2006). Activity limitation in hemiplegic cerebral palsy: evidence for disorders in motor planning, Developmental Medicine and Child Neurology, 48(9), 780-3.

10. Kuhtz-Buschbeck J.P., Sundholm L.K., Eliasson A.C., Forssberg H. (2000). Quantitative assessment of mirror movements in children and adolescents with hemiplegic cerebral palsy, Developmental Medicine and Nhild neurology, 42(11),728-36.

11. Zielinski I.M., Green D., Rudisch J., Jongsma M.L., Aarts P., Steenbergen B. (2017). The relation between mirror movements and non-use of the affected hand in children with unilateral cerebral palsy, Developmental Medicine \& Child Neurology, 59(2), 152-9.

12. Adler C., Berweck S., Lidzba K., Becher T., Staudt M. (2015). Mirror movements in unilateral spastic cerebral palsy: Specific negative impact on bimanual activities of daily living, European Journal of Paediatric Neurology, 19(5), 504-9

13. Nass R. (1985). Mirror movement asymmetries in congenita1 hemiparesis The inhibition hypothesis revisited, Neurology, 35(7), 1059.

14. Zielinski I.M., Green D., Rudisch J., Jongsma M.L., Aarts P., Steenbergen B. (2017). The relation between mirror movements and non-use of the affected hand in children with unilateral cerebral palsy, .Developmental Medicine \& Child Neurology, 59(2), 152-9.

15. Fedrizzi E., Pagliano E., Andreucci E. (2003). Hand function in children with hemiplegic cerebral palsy: prospective follow-up and functional outcome in adolescence, Developmental Medicine \& Child Neurology,45(2), 85-91.

16. Steenbergen B., Charles J., Gordon AM. (2008). Fingertip forccontrol during bimanual object lifting in hemiplegic cerebral palsy, Experimental Brain Research, 186(2), 191201. 